\title{
DOES PUBLIC ADMINISTRATION HIGHER EDUCATION IN CEECS REFLECT DEMANDS CREATED BY NPM REFORMS?
}

\section{Juraj Nemec}

Matej Bel University, Faculty of Economics, Banska Bystrica, Slovakia;

Banking Institute Prague, Praha, Czech Republic, e-mail: juraj.nemec@umb.sk.

\section{David Spacek}

Masaryk University, Faculty of Economics and Administration, Brno, Czech Republic, e-mail: david.spacek@econ.muni.cz.

\section{Patrycja Suwaj}

University Bialystok, Faculty of Law, Poland, e-mail: psuwaj@wsap.edu.pl.

\section{Artur Modrzejewski}

University Bialystok, Faculty of Law, Poland, e-mail: artasm@wp.pl.

\begin{abstract}
The first part of the paper summarizes NPM approaches in public administration reforms in the countries of Central and Eastern Europe (CEECs), and focuses particularly on contracting of public services delivery, outsourcing of supportive services in public organizations and Program (performance) budgeting and performance evaluation and financing. The problems discussed in the first part open a discussion on public management education of civil servants in CEECs with which deals the second part of the paper. The data available clearly indicate that the contents and quality of public management higher education in the three selected countries Slovakia, Czech Republic and Poland - do not meet the current needs of a modern state.
\end{abstract}

Keywords: NPM, public management reforms in CEECs, civil servants' education

JEL Classification: H79, I21

DOI: $10.2478 / \mathrm{v} 10135-011-0010-2$ 


\title{
DOES PUBLIC ADMINISTRATION HIGHER EDUCATION IN CEECS REFLECT DEMANDS CREATED BY NPM REFORMS?
}

\author{
Juraj Nemec ${ }^{1}$, David Špaček ${ }^{2}$, Patrycja Suwaj ${ }^{3}$, Artur Modrzejewski ${ }^{4}$
}

\section{Introduction}

Education and training of civil servants were perceived as the fundamental mechanism for helping former communist bloc countries to come through the current transitional phase, and civil servants education should have aimed to create civil servants with the following three types of competence (Balducci, 1995): a capability to operate successfully in the existing situation, knowledge of management techniques in more advanced organizations (psychological leadership techniques and management control techniques), and an understanding of techniques of organizational development, project management and policy analysis that would provide for activation and management of the process of changes.

Education of civil servants still represents one of the dominant aims of public administration reform and modernization among countries of Central and Eastern Europe (CEECs) (Hajnal, 2004; Nemec, 2006). Improvement of civil servants education has been particularly emphasized as a tool that could enhance the capacities of public administration to implement public policies and reform strategies. But even in 2006, Dunn, Staroňová and Pushkarev (2006) thought that insufficient qualification of public employees affected the very ability of government to implement its policies and programs. In addition, the educational opportunities in CEE countries in the areas of policy design, analysis and implementation were insufficient or non-existent (Dunn, Staroňová and Pushkarev, 2006). According to the OECD (2008), another challenge is the need to develop and maintain an adequate managerial capacity and competence in those organisations that are authorised to handle their own human resources. This may also be the case for self-governing sub-national authorities, of which the regional level may represent a relatively new part of the post-communist administrative systems.

Our paper is based on our own research studies of both public sector performance and public management education in Central Europe. ${ }^{5}$ It is mainly based on data from the Czech Republic, Slovakia and Poland. Data collected about the success and failures of outsourcing, contracting and performance management by our team, but also by many others (e.g. Dunn, Staroňová and Pushkarev, 2006; Bouckaert et al., 2008; Brusis, Staroňová and Zubek, 2007; or Wright and Nemec, 2002), indicate that these "market

\footnotetext{
${ }^{1}$ Matej Bel University, Faculty of Economics, Banska Bystrica, Slovakia, Slovakia, and Banking Institute Prague, Czech Republic e-mail: juraj.nemec@umb.sk.

${ }^{2}$ Masaryk University, Faculty of Economics and Administration, Lipová 41a, 60200 Brno, Czech Republic, e-mail: david.spacek@econ.muni.cz.

${ }^{3}$ University Bialystok, Faculty of Law, Poland, e-mail: psuwaj@ wsap.edu.pl.

${ }^{4}$ University Bialystok, Faculty of Law, Poland, e-mail: artasm@wp.pl.

${ }^{5}$ The preparation of this paper was supported by the Czech Grant Agency GACR, project "Optimalizace outsourcingu ve veřejném sektoru", number P 403/10/1892.
} 
based" approaches do not deliver "Value for Money" in many if not most CEECs. Such a situation naturally motivates research on the reasons for such limited success. Among many potential factors, quality of education and training in public management (market based approaches cannot be successfully realized by incompetent administrators) was identified, and we decided on an in-depth investigation of this dimension in three new CEE EU member states.

In the line with the facts mentioned above, the main goal of our paper is to determine if the public sector need for effective public management education is reflected by higher education institutions. Our research questions are:

1. How many public management (bachelor and master) programmes are delivered in the selected countries? Do programs labeled as public management really represent public management programmes from the point of view of their curricula content? What explains the situation?

2. What is the proportion of public management courses in the curricula of accredited public administration programmes delivered in selected countries? What explains this proportion?

3. What are the dominant teaching approaches used for delivery of public management courses?

In our research, we distinguish three types of programmes currently available:

a) Public management programmes - to be included in this group, as a minimum the programme must include public financial management, e-governance or similar, human resources management and strategic management in the public sector.

b) Mixed programmes - programmes with some public management or related courses, but not covering the minimum list of the aforementioned courses.

c) Classical administration programmes - programmes with a major focus on law and administration.

Two main methods of data collection were used - analysis of relevant and relatively reliable web pages (information about the structure of programmes derived from web pages of accreditation committees and the information on curricula structure, and content derived from web pages of higher education institutions, universities and/or their faculties) and interviews with representatives of civil servants. Some arguments in the text are also based on the existing personal experience of authors (involved in the national and international accreditation processes). Based on our local experience, we formulated two working hypotheses:

1. Few real public management programmes will be found.

2. The course information lists and experience will show that classic teaching (lecturing and memorizing) is still the main delivery methods. 


\section{New public management approaches in CEECs' reforms and their selected results}

In this first part we briefly introduce experience with market based public sector reforms in the region. The goal is to create a "background" for the core parts of our paper, analyzing the current situation of public administration higher education - the comprehensive information about NPM reforms in CEE was already published for example by the NISPAcee sources.

As indicated by (Bouckaert et al., 2008) all CEECs implemented some "market" - NPM elements in reforming their public sectors after 1989 (Table 1):

Table 1: Classification of reforms in Central Europe

\begin{tabular}{|c|c|}
\hline Country & Reform type \\
\hline $\begin{array}{l}\text { Czech } \\
\text { Republic }\end{array}$ & $\begin{array}{l}\text { Predominantly incremental and legalistic reforms during the entire } \\
\text { evaluated period. Few management reforms after } 2000 \text {. Liberal } \\
\text { governments elected in } 2006 \text { and } 2010 \text { proposed several more radical } \\
\text { NPM changes, some of them implemented. }\end{array}$ \\
\hline Estonia & $\begin{array}{l}\text { Estonian reforms seem to be the most radical and NPM based. The } \\
\text { central aim in Estonian public administration has not been to build a } \\
\text { solid ground for democracy but to improve efficiency of public } \\
\text { institutions. Yet, as a consequence of the policies adopted by successive } \\
\text { neo-liberal governments, the underlying theme behind government } \\
\text { reform initiatives has been decreasing the role of the state. Recent } \\
\text { governments, because of predominantly negative experiences with } \\
\text { NPM, have re-evaluated such approaches. }\end{array}$ \\
\hline Hungary & $\begin{array}{l}\text { Hungarian reforms can be characterized as the mixed model, starting } \\
\text { with a predominantly incremental and legalistic reform approach in the } \\
\text { early nineties, slowly changing to a mixed type, with a radical NPM } \\
\text { switch in the post- } 2006 \text { period. Current NPM changes focus on two } \\
\text { central elements - downsizing and radically reforming the human } \\
\text { resource management system. }\end{array}$ \\
\hline Latvia & $\begin{array}{l}\text { From its beginning to the current reform activities, Latvian reforms can also } \\
\text { be characterized as the mixed model. Several NPM types of reform changes } \\
\text { were implemented, especially in the later phases of reforming the public } \\
\text { administration system, but NPM never dominated the reform strategies. }\end{array}$ \\
\hline Lithuania & $\begin{array}{l}\text { In the pre-accession period, Lithuanian public management reform was } \\
\text { characterized by ad hoc and sectoral efforts. The first two attempts at } \\
\text { comprehensive reform in } 1995 \text { and } 1997 \text { were unsuccessful. More } \\
\text { intensive competition over NPM type reforms only began in the post- } \\
\text { accession period. }\end{array}$ \\
\hline Poland & $\begin{array}{l}\text { Poland is the typical representative of the prevailing legalistic approach } \\
\text { to the reforms. NPM had limited impact on Polish administration, by } \\
\text { providing ideas and demands for recognition of the need to modernize } \\
\text { Polish administration, and at the same time reducing its size. }\end{array}$ \\
\hline
\end{tabular}




\begin{tabular}{|c|c|}
\hline Slovakia & $\begin{array}{l}\text { Before } 2003 \text {, the reform was dominantly incremental and legalistic, with } \\
\text { few NPM ideas realized. During the second election period of the } \\
\text { liberal prime minister Dzurinda administration (2003-2006), radical } \\
\text { NPM changes were made, for example massive decentralization and } \\
\text { introducing performance financing schemes. Prime minister Fico`s } \\
\text { coalition, in power from 2006, returned to the concept of a powerful } \\
\text { state dominating public delivery functions. }\end{array}$ \\
\hline Romania & $\begin{array}{l}\text { Though the concept of public management has not always intertwined } \\
\text { with the reform of public administration, some new managerial ideas, } \\
\text { such as the use of contractualisation, strategic management and } \\
\text { planning, performance measurement systems, and reform networks, } \\
\text { were included in reform packages. }\end{array}$ \\
\hline
\end{tabular}

Source: Adopted from Nemec, 2008.

\subsection{Selected results of "NPM type" changes in CEECs}

Few articles discuss the results of implementing market type mechanisms in the public sector of CEECs. The research is fragmented and pays too little attention to NPM instruments described by the international literature. Here we briefly summarize existing research approaches relative to the selected NPM mechanisms.

\subsubsection{Contracting of local public services delivery}

Contracting of local public services is a very frequent delivery solution in CEE. Several experts have dealt with the issue (Péteri and Horvath, 1996 and 2001, and Zoltán, 1996 for Hungary, Pavel, 2006 and Ochrana et al., 2007 for the Czech Republic, Tonnisson and Wilson, 2007 for Estonia, and Meričková, 2001, 2005, 2006, Meričková and Majlingová, 2005, Beblavý and Sičáková-Beblavá, 2006 and 2007, Sičáková-Beblavá, 2009; Majlingová and Šagát, 2006 for Slovakia, or Setnikar-Cankar et al., 2009 for Slovenia). Their results are very similar. In summary:

a) Contracting local public services is a common solution (on average about $50 \%$ of services are delivered on the base of a contract).

b) Contracting local public services does not commonly deliver the required "Value for Money" (lower costs and/or increased quality). We document this fact using as an example the most clearly visible, though not fully reliable, data of Slovakia, derived from repeated research (Table 2). The data indicate that upon comparison of internal and external forms of delivery, there is no general trend in unit costs. The results also differ across similar municipalities. In some cases, municipalities pay more for the service than it costs in similar conditions elsewhere (Pavel, 2009a and 2009b). This situation persists in part because regular performance benchmarking is not the rule in Slovakia, Czech Republic and most of the other CEE countries (Nemec, Vítek and Meričková, 2005). 
Table 2: The economy of contracting local public services in Slovakia (internal delivery direct costs $=\mathbf{1 0 0 \%}$ )

\begin{tabular}{|l|c|c|c|c|c|}
\hline \multicolumn{1}{|c|}{ Service } & 2001 & 2005 & 2006 & 2008 & 2009 \\
\hline Waste management & 94 & 94 & 125 & 184 & 60 \\
\hline Cemeteries & 64 & 13 & 67 & 146 & 66 \\
\hline Public greenery & 82 & 192 & 150 & 151 & 133 \\
\hline Maintenance of local communications & 70 & 109 & 119 & 114 & 104 \\
\hline Maintenance of local lighting & 100 & 138 & 128 & 156 & 127 \\
\hline
\end{tabular}

Source: Merickova et al., 2010

\subsubsection{Outsourcing of supportive services in public organizations}

Outsourcing for supportive services is a less frequently investigated issue, but existing data show that it is also a relatively frequent solution in CEE. The outcomes from outsourcing have started to be investigated only recently, and we can provide two different examples of them. Šumpíková-Fantová (2010, unpublished) collected the data on outsourcing of IT from 83 public administration offices. Her results are summarised in Table 3.

Table 3: Costs and quality of outsourced IT services in Czech public administration offices

\begin{tabular}{|l|c|c|}
\hline & $\begin{array}{c}\text { Costs per } \\
\text { employee }\end{array}$ & $\begin{array}{c}\text { Quality (evaluated by employees, maximum } \\
100)\end{array}$ \\
\hline Internal delivery & 3733 & 52 \\
\hline Outsourcing & 3348 & 56 \\
\hline
\end{tabular}

Source: Šumpíková-Fantová (2010, unpublished)

The data collected by Šumpíková-Fantová are relatively positive; however our own data are less optimistic. To avoid the problem of limited reliability of the data obtained from public bodies, our 2009 study involved direct research within selected bodies, using their own accounting data. The sample was not representative but the fact that all 10 investigated decisions were uneconomic is noteworthy.

\subsubsection{Program (performance) budgeting and performance evaluation and financing}

Estonia and Slovakia are the countries where performance tools were introduced on a large scale. Other countries use performance financing for selected branches (like education), or have recently switched to program budgeting on the national level. Several implementation problems are reported (Drechsler, 2005).

If program performance budgeting is implemented by top - down order and in a bureaucratic fashion, it merely increases costs. In the Czech Republic the combination of performance financing for public schools and fee based financing for private schools may be one of the main influences behind the fact that the higher education system may 
soon be ready to accept about $90 \%$ of the relevant age group, which is clearly excessive. Financing higher education predominantly on the number of students delivers too many perverse effects. At the start of the performance financing system in Slovakia, about $80 \%$ of universities` revenues came from public grants based on the number of students. With this the management of a university was allowed to maximize the level of the public grant by maximizing the number of accepted students. This is what happened: the number of students almost doubled in the three years 2004-2007 (www.minedu.sk). But as the state budget allocation did not increase with inflation, the quality of education decreased (ARRA quality evaluation reports - www.arra.sk or Ciaian et al, 2005).

\section{Public management education in Poland, Czech Republic and Slovakia}

In addition to some general and well-known factors (see for example Pollit and Bouckaert, 2004), there are several region-specific factors that may help explain the limited success of NPM tools in the CEE environment. Some of them are:

a) Limited competitiveness and short-term business strategies.

b) "Under-developed" democracy, where citizens are incapable of acting as the watchdog for government's malfunctions.

c) Limited "Quality of the state of law".

d) Territorial fragmentation in some CEE countries.

e) Relatively widespread and deep corruption in most CEE countries.

As indicated above, this article wants to add an extra dimension to this list - the factor of public management education in the region, its scope and quality, focus on characteristics of public administration programmes as offered by higher education institutions in Poland, the Czech Republic and Slovakia. In this chapter we summarize our research (Nemec, Špacek and Suwaj, 2009; Nemec, Špacek, Suwaj and Modrzejewski, 2010) on the scale of public management (bachelors and masters) programmes, the proportion of public management courses in the curricula of accredited public administration programmes and the dominant teaching approaches used for delivery of public management courses.

\subsection{The scale of public management (bachelors and masters) programmes}

\subsubsection{Poland}

The most common way of studying public administration in Poland, by number of students, are private or non-public High Schools (Wyższa Szkoła). The large network of schools offering bachelors' and some of them also masters' degrees is accredited by the Polish National Accreditation Committee. But from the outset it should be noted that according to Polish legal regulations (Regulation of Minister of Science and Higher Education, from June 13, 2006; Dz. U. 2006, Nr 131, poz. 838) there is no official Polish Public Management programme, so public management can only be a specialization offered within an officially accredited programme, such as administration or management.

The programmes that include public administration include Administration, Public Health, Social Policy, and National Security. Administration has the largest number of 
students. Unable to obtain a full picture of all types of programs, we decided to focus on Administration as a program being a subject to accreditation. 17 public universities, 4 technical universities, 3 universities of economics, 2 pedagogical universities and 88 non-public or private higher schools in total offer such a programme.

The higher education system has only limited capacity to train public managers. Amongst the 114 schools for which we have acquired any data, there are only two nonpublic delivered programmes with a public management dimension as a specialization in their Administration Programmes, and neither of them fully complies with our definition of a public management programme. They are:

- specialisation Management of Public Organizations offered by the Stanislaw Staszic School of Public Administration in Bialystok,

- specialisation Management in Administration offered by the Higher School of Management and Banking in Poznan.

To obtain more complete and detailed results, we investigated programmes of management in all universities. Public management types of programmes exist as a specialization in the following schools:

- as the specialisation within Management Programmes: Warsaw University, Jagiellonian University in Cracow, University of Lodz, Szczecin University, The Jan Kochanowski University of Humanities and Science in Kielce, and Bialystok Technical University;

- as the specialisation within a Social Policy Programme: Jagiellonian University Cracow,

- as the specalisation within an Economics Programme: Cracow University of Economics.

From this sample real (according to our classification) public management programmes are delivered by Jagiellonian University, the University of Lodz, and Cracow University of Economics.

Our analysis clearly indicates that the legal and administrative approach to public administration education in Poland dominates as the result of the Polish standards for Administration Programs (Tables 4 and 5).

Table 4: Minima for Administration Programme, Bachelor level (three years study)

A. BASIC COURSES

1. Introduction to the law

2. History of administration

3. Public administration

4. The constitutional system of public organs

5. Administrative law

6. Administrative procedures 
7. Organization and management in public administration

8. Macro- and micro-economics

9. Public economy law

\section{B. SPECIFIC PROGRAM COURSES}

1. Civil law and contracts in administration

2. Labour law and public officials' law

3. Public finances and finance law

4. Sociology and methods of social analysis

5. Public procurement

6. Criminal law

7. EU institutions and law

8. Statistics and demography

9. Administrative legislation

10. Executing administrative procedures

11. Techniques of negotiation and mediation in administration

12. Local-government organization

Table 5: Minima for Administration Program, Masters level (two years study)

\begin{tabular}{l}
\hline A. BASIC COURSES \\
\hline 1. Rules for political organization of the state \\
2. Judicial-administrative procedure \\
3. EU funds \\
4. The history of organizational-administrative and socio-economical ideas \\
\hline B. SPECIFIC PROGRAM COURSES \\
1. The system of legal protection in the EU \\
2. HR Management \\
3. Social policy and the social security system \\
4. Criminal-tax law \\
5. Sociology of organizations \\
6. Drafting EU projects
\end{tabular}




\subsubsection{Czech Republic}

Thanks to the smaller size of the country and the high level of availability of information on the web of the Czech Accreditation Committee, we were able to map all programmes which are considered to be equal for educational requirements for civil servants.

At the beginning of 2009, fifty-one accredited study programmes related to public administration and the public sector were offered in the Czech Republic. Public administration programmes in a broader sense are and can be delivered, according to national accreditation rules, by many study branches, as enumerated in the regulation. Most of these study programmes were entitled "Economic Policy and Administration", and a smaller number of these was called "Regional Development". Less common were the programmes entitled Public Policy, Public Administration, Economics and Management, Territorial Studies, Regional Development, Social Policy and Social Work, System Engineering and Informatics, Sociology, and International and Public relations. Such heterogeneity could lead one to anticipate existence of several different forms of public management programmes. But this was untrue.

We analyzed all 51 existing programmes, with the following results:

a) Public Management programmes - 0

b) Mixed programmes - 29

c) Classical administration programmes -22 .

These findings show that despite the fact that many administration programmes are delivered by faculties of economics ("economics" in the Czech Republic means business), there is no pure public management programme in the Czech Republic, . Some programmes have titles that may indicate a public management focus - especially the MVŠ Olomouc programme Management and Public Sector Economy. But an analysis of the curricula clearly shows that the programme is mixed.

\subsubsection{Slovakia}

For Slovakia, we are able to provide a full list of existing programmes with national accreditation, drawing on information on the web pages of the Accredditation Commission - www.akredkom.sk - and of the Ministry of Education www.education.gov.sk

According to national accreditation rules, public administration programmes in a broader sense are and can be delivered in the following study branches - Public Administration and Regional Development, Public Economics and Services, and Public Policy and Public Administration. We analyzed all 14 existing programmes with the following results:

a) Public Management programmes - 0

b) Mixed programmes - 3

c) Classical administration programmes -11 .

As with the Czech Republic, we were not able to identify any purely public management programme in Slovakia. 


\subsection{The proportion of public management courses in the curricula of accredited public administration programs}

In this phase of our research we tried to obtain as much information as possible about the contents of public administration programmes in all three countries. For Slovakia, an analysis of all 14 programmes was possible. For Poland and the Czech Republic this was not possible, so we chose representative samples. For Poland - 26 "Administration" programmes, only at bachelor level; and for the Czech Republic 36 programmes are included in the summary Table 6. To simplify the analysis, we focused only on compulsory curricula elements.

Our main problem was with Poland, with too large a diversification of study branches. In addition to analyzing bachelor's programmes in public administration, we also tried to collect more data about public management education delivered by other than "Administration" programmes. Such analysis once more confirmed our opinion that some university programmes with the name "public management" or similar are in fact not public management programmes. The Management and Organisation in public administration in Poznan was the most obvious example - their curriculum includes only general management courses. On the other hand, we discovered one "almost public management" programme - Management in Public Administration at the Silesian Politechnique.

In Table 6, we provide summary data on the proportion of public management, general management and mixed courses in public administration curricula in all three selected countries.

Table 6: Percentage of selected courses from total number of credits

\begin{tabular}{|l|c|c|c|c|c|c|}
\hline & \multicolumn{2}{|c|}{ Czech Republic } & \multicolumn{2}{c|}{ Poland } & \multicolumn{2}{c|}{ Slovakia } \\
\hline Level of Degree & I & II & I & II & I & II \\
\hline $\begin{array}{l}\text { Public } \\
\text { management }\end{array}$ & $1 \%$ & $6 \%$ & $1 \%$ & $\mathrm{x}$ & $1 \%$ & $9 \%$ \\
\hline $\begin{array}{l}\text { General } \\
\text { management }\end{array}$ & $7,5 \%$ & $8 \%$ & $1,5 \%$ & $\mathrm{x}$ & $7 \%$ & $4 \%$ \\
\hline Mixed & $4 \%$ & $8,5 \%$ & $1 \%$ & $\mathrm{x}$ & $5 \%$ & $11 \%$ \\
\hline
\end{tabular}

Source: own research

For Slovakia and the Czech Republic, the "summary" patterns are relatively similar. Public management courses are rarely delivered at an undergraduate level (including mainly general management and mixed courses). But at a postgraduate level public management is better represented.

In Poland, the core standard "Administration" programme curricula are predominantly legal and do not prepare public managers for their functions. Despite the fact that the national curricula expects the course Organization and Management in Public Administration to be delivered by all undergraduate "Administration" programmes, about a third of schools have no such course. Moreover, this course is also delivered with very different syllabi - in some schools it includes very little of what it should. 
A large proportion of different "Economics" is the specific issue for Slovakia and the Czech Republic. This is a clear heritage of the previous regime when it was common to name courses in such a way.

In Table 7 we provide information about the frequency of public management courses delivered by the whole sample of public administration programmes for all three countries.

Table 7: Public management courses in curricula of selected programmes

\begin{tabular}{|c|c|c|c|}
\hline \multirow[b]{2}{*}{ Course } & \multicolumn{3}{|c|}{ Number of such courses in the national sample } \\
\hline & $\begin{array}{c}\text { Poland [26 } \\
\text { "Administration" } \\
\text { programmes] }\end{array}$ & $\begin{array}{l}\text { Czech Republic } \\
\text { [36 programmes] }\end{array}$ & $\begin{array}{l}\text { Slovakia [18 } \\
\text { programmes] }\end{array}$ \\
\hline $\begin{array}{l}\text { Organization and } \\
\text { Management in PA }\end{array}$ & 18 & 0 & 0 \\
\hline $\begin{array}{l}\text { Public Management, } \\
\text { Management in PA }\end{array}$ & 0 & 9 & 1 \\
\hline $\begin{array}{l}\text { Organization and } \\
\text { Management of Public } \\
\text { Economy/Sector }\end{array}$ & 0 & 0 & 7 \\
\hline $\begin{array}{l}\text { Territorial, City, PA } \\
\text { Marketing }\end{array}$ & 0 & 5 & 6 \\
\hline $\begin{array}{l}\text { Territorial, City } \\
\text { Management }\end{array}$ & 0 & 3 & 4 \\
\hline $\begin{array}{l}\text { Financial Management } \\
\text { in the Public Sector }\end{array}$ & 0 & 1 & 3 \\
\hline $\begin{array}{l}\text { Control and Audit in } \\
\text { the Public Sector }\end{array}$ & 0 & 8 & 1 \\
\hline Applied HRM & 1 & 2 & 1 \\
\hline $\begin{array}{l}\text { Project Management in } \\
\text { PA }\end{array}$ & 0 & 3 & 0 \\
\hline Quality in PA & 0 & 2 & 0 \\
\hline
\end{tabular}

Note: We place very similar courses with slightly different names under the same heading. Source: own research

Table 7 is really interesting. First, it shows that the role of a national curriculum is really visible only in Poland, even though such national curricula exist and are also part of accreditation review in the other two countries. Second, in the case of Slovakia and the Czech Republic it clearly documents how programme curricula are developed. It is not the best international practice but national direct and indirect agreements, connected to the previous system, plus the qualification of staff that define the curricula contents. 


\subsection{Dominant teaching approaches used for delivery of public management courses}

In our research we tried to collect as much information as possible about teaching methods and approaches for the selected programmes. The main issues were teaching methods, examination methods, literature used, and workload. We can summarize the main findings as follows:

A) Lecturing is still the dominant teaching method.

B) Written multiple-choice tests and oral examinations dominate as test methods. Final examinations are starting to include an essay in an increasing number of courses. Quality and method of reviewing written essays is an open issue. Copyright issues have only recently begun to be important in all three countries, and then only at a final thesis level. In our personal experience, in many cases such an essay is simply a copy and paste exercise. A double review system for essays is unknown.

C) Local sources dominate when it comes to literature. In some cases, recent international textbooks were included in the list. However, not all students in any of the participating countries speak English, which may mean that such literature is just recommended, or formally included to provide a comprehensive list of sources. Yet it is not really used. Our experience is that in many schools knowledge of only one local book, or even just slides and lecture notes, is sufficient to pass the examination.

D) The number of teaching hours and the number of teaching hours and real workload per credit unit in particular differ among schools, in some cases excessively. In addition to that, curricula in public schools - especially in Slovakia and the Czech Republic - seem to be too fragmentized.

\section{Could the quality of public management education in CEECs be the one possible explanatory factor for the limited success of NPM approaches?}

There is no doubt that the effective implementation of market type - NPM tools and approaches requires highly qualified, flexible public managers. Our research data suggest that the higher education of public sector specialists in the three selected CEE countries - and systems in other countries in the region are very similar - does not meet public sector needs. Due to this, it insufficiently reflects international quality standards. For example, the "Standards of Excellence for Public Administration Education and Training" prepared by the United Nations Department of Economic and Social Affairs together with the International Association of Schools and Institutes of Administration. Along with many other standards this document advocates:

"A Curriculum that is Purposeful and Responsive

A principal goal of public administration education and training is the development of public administrators who will make strong, positive contributions to the public service generally and, in particular, to the organizations they join, or to which they return."

On the basis of our findings we may also argue that major gaps exist on the education side between delivery and desirable standards. The gaps particularly relate to the lack of appropriate programmes and teaching methods. 
On the scale and content of public management programmes, the following points are relevant (these statements are derived from the analysis of syllabi and from the data obtained by authors during their public administration higher education accreditation related activities):

A) The national accreditation system is a barrier for development of public management programmes because the subject is not recognized as a discipline in any of the sample countries.

B) The entry employment conditions regulated by Civil Service and Public Service Codes prescribe bachelor or masters level education for all statutory civil servants in all three countries. But there is no explicit requirement for entrants to have studied any particular subjects.

C) The system of training of public officials does not provide clear and direct incentives for developing public management courses and programmes. Civil servants are trained to administer and not to manage. During their careers, most civil servants have to pass basic administrative training and professional administrative courses, rather than job specific management training.

D) Public sector does not demand public managers. We confirmed this statement by a small scale indicative research project in Poland. A questionnaire was sent to selected institutions at all levels of government. There were 16 responses. No response directly stated that the office needed public managers. Some answers, especially from ministries, indicated that the priority, respecting the civil service legislation, is public administration and law graduates.

E) Both national and programme curricula are developed on the basis of tradition and "supply" capacities and not on the basis of international standards and "need and demand".

In relation to teaching methods, our research leads to the following observations:

A) National rules may limit internationalization. For example, the Polish Law on the Polish Language creates an obligation to only use literature exclusively in Polish, if the language of instruction is Polish. Hence international documents must be translated into Polish, and this can delay information transfer. A professor can suggest but not require non-Polish books. In Slovakia, the National Accreditation Committee requires any school applying for accreditation to have its own textbooks on the main topics. So a book written by local teachers is the first listed textbook for almost all Slovak programmes. Such an approach does not guarantee access to the most up-to-date knowledge.

B) We feel that the unsatisfactorily low proportion of more active teaching methods is partly caused by widespread budgetary constraints. This is especially true in case of Slovakia where $90 \%$ of university revenues come from public sources, and the proportion of GDP spent on universities is the lowest in the EU. So teaching all students in one lecture group is attractive on grounds of cost. 


\section{Conclusions}

The high level of complexity of our topic prevented us from using quantitative methods to assess how closely the quality of public management higher education and the quality of public management practice are interrelated in our sample of CCE countries. Although it is almost impossible to establish robust statistical links between outputs of the higher education system and public management practice outcomes, we feel that such a link does exist. So the question in the title of our paper is answered by a qualitative analysis. This should be sufficient for our task. It is unnecessary and impossible to calculate what proportion of public sector performance failures is due to the lack of qualifications of those responsible for managing the processes.

Our data clearly show that the structure, contents and quality of public management higher education in all three selected countries, and hence probably the entire CEE region, do not reflect public sector needs, and are far behind international standards, especially the "Standards of Excellence for Public Administration Education and Training" prepared by the United Nations Department of Economic and Social Affairs together with the International Association of Schools and Institutes of Administration.

High quality public managers have to respond to the current needs of the "NeoWeberian"/public governance state (Drechsler, 2009), combining predictability, reliability and accountability with economy, efficiency and effectiveness, the latter achieved also by the standard and frequent use of several market mechanisms in the public sector. However, such managers are not effectively prepared by our education systems today.

\section{References}

BALDUCCI, M. (1995). Training Civil Servants in the Administrations of Central and Eastern Euorpe: A Missed Opportunity? International Review of Administrative Sciences, 1995, 61 pp. $61-72$.

BEBLAVY, M., SICAKOVÁ-BEBLAVA, E. (2007). Faktory ovplyvnujuce rozhodovanie o sposobe zabezpecovania sluzieb vo velkych slovenskych mestách. Politická ekomonie, 55:2 pp. 245-261.

BEBLAVY, M., SICAKOVÁ-BEBLAVA, E. (2006). Institucionalne dilemy pri zabezpecovani verejnych sluzieb. Presov: ADIN.

BOUCKAERT, G., NEMEC, J., NAKROŠIS, V., HAJNAL, G., TÕNISSON, K. (2008). Public Management Reforms in Central and Eastern Europe. Bratislava: NISPAcee Press.

BRUSIS, M., STAROŇOVÁ, K., ZUBEK, R. (2007). Strategic policy making in Central and Eastern Europe. Bratislava: NISPAcee Press.

CIAIAN, P., POKRIVCAK, J., AND RAJCANIOVA, M. (2005). Stav ekonomickej vedy na Slovensku. Finance a uver, 2005, 11-12(55), pp. 546-562 
DRECHSLER, W. (2005). The Re-Emergence of "Weberian" Public Administration after the Fall of New Public Management: The Central and Eastern European Perspective. Halduskultuur, 6 pp. 94-108.

DRECHSLER, W. (2009). The Rise and Demise of the New Public Management: Lessons and Opportunities for South East Europe. Uprava - Administration 7 (3), 2009, pp. 7-27.

DUNN, W. N., STAROŇOVÁ, K., PUSHKAREV, S. (2006). Implementation - the missing link. Implementation: the missing link in public administration reform in CEE. Bratislava: NISPAcee 2006.

HAJNAL, G. (2004). European Curricula in PA. EPAN conference, Budapest, 11.-12. 6. 2004.

MAJLINGOVA, L., SAGAT, V. (2006). Zabezpecovanie sluzieb miestnou samospravou. Acta Aerarii Publici, 3:2, pp. 35-41.

MERICKOVA, B. (2001). Partnerstvo sukromneho a verejneho sektora v procese poskytovania verejnych sluzieb na komunalnej úrovni na Slovensku. Ekonomika a spolocnost. 2:1 pp. 179-186.

MERICKOVA, B., MAJLINGOVA, S. (2005). Benchmarking v zabezpecovani sluzby zberu a likvidacie tuheho komunalneho odpadu. Verejna sprava, 60:4 pp. 22-23.

MERICKOVA, B. (2005). Alternativne pristupy $k$ poskytovaniu miestnych verejnych sluzieb. Banska Bystrica: Ekonomicka fakulta UMB.

MERICKOVA, B. (2006). Vybrane problemy parterstva verejneho a sukromneho sektora. Banská Bystrica: Ekonomicka fakulta UMB.

MERICKOVA, B., NEMEC, J., SICAKOVA-BEBLAVA, E., BEBLAVY, M. (2010) Kontrahovanie sluzieb vo verejnom sektore. Presov: ADIN.

NEMEC, J., VÍTEK, L., MERIČKOVÁ, B. (2005). Contracting-out at Local Government level: Theory and Selected Evidence from Czech and Slovak Republics. Public Management Review, 7:4 pp. 638-647.

NEMEC, J., SPACEK, D., SUWAJ, P. J. (2009). Public management education in Central Europe: how far did we progress? Paper prepared for EGPA 2009 conference.

NEMEC, J., SPACEK, D., SUWAJ, P. J., MODRZEJEWSKI, A. (2010). Public management education in Central Europe: how far did we progress - II? Paper prepared for EGPA 2010 conference.

NEMEC, J. (2006) EAPAA peer review accreditation and its potential to strengthen PA education: the case of CEE countries. Bratislava: NISPAcee.

NEMEC, J. (2008). Public Management Reforms in CEE: Lessons Learned. Public Management Reforms in Central and Eastern Europe. Bratislava: NISPAcee Press, pp. 343-371.

OCHRANA, F., SUMPIKOVA, M., NEMEC, J., PAVEL, J., MERICKOVA, B. (2007). Efektivnost zabezpečování vybraných veřejných služeb na úrovni obcí. Praha: Oeconomica. 
OECD (2008). The State of the Public Service.

PAVEL, J. (2006). Efektivnost a transparentnost obecnich obchodnich spolecnosti. Praha: Transparency International Czech Republic, 2006.

PAVEL, J. (2009a). Verejne zakazky v CR. Praha: Halkova nadace.

PAVEL, J. (2009b). Efektivnost fungovania kontrolnych systemov verejneho obstaravania na Slovensku. Bratislava: TIS.

PETERI, G., HORVÁTH, T. M. (1996). Management of Local Communal Services. Market - Competitive - Contract. Birmingham: Institute of Local government Studies, University of Birmingham, pp. 15-34.

PETERI, G., HORVATH, T. M. (2001). Regulation and Competition in Local Utilities Sector in Central and Eastern Europe. Navigation to the Market. Budapest: Open Society Institute/Local Government and Public Sector Reform Initiative, pp. 13-98.

POLLITT, CH., BOUCKAERT, G. (2004). Public Management Reform a Comparative Analysis. London: Oxford University Press.

SETNIKAR-CANKAR, S., SELJAK, J., PETKOVŠEK, V. (2009). Awarding work to external contractors in Slovenian municipalities. Third International Symposium on the Development of Public Administration in South East Europe, 18 - 19 June 2009, Ljubljana, Slovenia, University of Ljubljana.

SICAKOVA-BEBLAVA, E. (2009). Methods and transparency in services provision in Slovak cities. Central European Journal of Public Policy. 3:1 pp. 4-16.

TONNISSON, CH., WILSON, J. (2007). Best Value in transitional countries? Public Management Review, 9: 1 pp. 87-106.

WRIGHT, G. NEMEC, J. eds. (2002). Management verejne spravy: Teorie a praxe. Praha: EKOPRESS 2002.

ZOLTAN, K. (1996). Ownerships and Organisations Forms of Communal Services Unit. Market - Competitive - Contract. Birmingham: Institute of Local government Studies, University of Birmingham, pp. $38-61$.

web pages of Czech, Polish and Slovak schools

www.akredkom.sk

www.education.gov.sk

http://www.msmt.cz/vzdelavani/akreditacni-komise

www.arra.sk

www.modernaskola.sk

www.eapaa.org

www.iiasiisa.be 